\title{
Human-Machine Collaboration as a Factor of Labour Productivity and Efficiency
}

\author{
Vladimir Menshikov, Professor, Dr.soc. \\ Irena Kokina, Professor, Dr.psych. \\ Vera Komarova, Dr.oec. \\ Daugavpils University, Latvia \\ Evgeniy Korshenkov, Mg.oec. \\ Baltic International Academy, Latvia
}

Doi:10.19044/esj.2020.v16n13p1 ～URL:http://dx.doi.org/10.19044/esj.2020.v16n13p1

\begin{abstract}
This article is aimed to give an empirical answer to the following research questions: 1) whether work as a type of activity and as a life value is losing its significance in the modern world; 2) whether human-machine collaboration (HMC) is a significant factor of labour productivity and efficiency. The authors suppose, that in the market economy labour productivity "merges" with its efficiency - in contrast to a planned economy. Thus, it is possible to talk about "labour efficient productivity" or simply about labour productivity. The methods applied for empirical study are the following: analysis of statistics, regression analysis and correlation analysis. Eurostat and Latvia's statistics as well as data of the World Values Survey and data collected by the World Economic Forum and other international organsations. Results of the empirical research show that despite the increase in employment rate in the EU as a whole and in Latvia in particular, work as a type of activity and as a life value is losing its significance in the modern world. HMC empirically is measured by two indicators which show the potential of a country in HMC: digital skills of the population and ICT adoption. Results of the analysis show that HMC is a significant factor of labour productivity in the modern world, while various components of HMC have different significance in two groups of the world countries. In countries with a high potential of HMC, including Latvia, digital skills of the population is the determinant of labour productivity. In its turn, in countries with a low potential of HMC, the main factor of labour productivity is ICT adoption.
\end{abstract}

Keywords: Human-machine collaboration, labour productivity and efficiency, productivity paradox, work, Latvia 


\section{Introduction}

The American economist, the author of the theories of the so-called "new economic geography", P. Krugman in 1990s argued that the most important way by which you can achieve the sustainable growth of living standards is to increase productivity and efficiency (Krugman, 1997). In scientific publications, as the main modern economic problem related to labour productivity and efficiency, is called the slowdown of their growth rates, which is global in general, but is most expressed in economically developed countries and especially in Europe (Kasyanovs, 2019). For this reason, over the past decades, economists and various international organizations, such as the International Monetary Fund and the OECD, have paid increased attention to this phenomenon, analyzing the reasons that could explain the slowdown in labour productivity and efficiency, and proposing measures that would overcome stagnation during their growth (David, 1990; Basu, Kimball, 1997; McMillan, Rodrik, 2011; OECD, 2015; International Monetary Fund, 2016; Adler et al., 2017).

In the study of labour productivity and efficiency in the 21 st century, the authors see the presence of two visible trends that deserve special attention of researchers and political decision-makers in the field of mass education and employment.

Firstly, the decline in the role and subjective significance of work $^{1}$ as a type of activity and as a life value in a modern world, which became the main theme of the book published in January 2020 by the British economist and political analyst D. Susskind, "A World Without Work: Technology, Automation and How We Should Respond" (Susskind, 2020). According to V. Vinge, "highly productive work becomes the matter of the steadily shrinking narrow elite of mankind" (Vinge, 2001, p. 26) (see also the concept of elites, which, as A. Giddens noted, is a kind of rejection of class analysis and juxtaposition of "elites" and "masses", but not classes - Giddens, 1989). Thereat, mass education - and even all traditional education - ceases to be a "motor" or an accelerator of labour productivity (Vinge, 2001).

The authors believe that the distinctive feature of this "steadily shrinking narrow elite of mankind" is the ability not to oppose machines, not to compete with them (as it is common, for example, among translators who are often very wary of machine translation capabilities (Skadin'a et al., 2012; Skvortsova, Tikhonova, 2016), - especially in countries with a low level of technological development, ${ }^{2}-$ which, according to the authors of the article,

\footnotetext{
${ }^{1}$ This term is used in economic literature (and in this research too) in two essentially different meanings - as production activity, i.e. work (Mosselmans, White, 2001), and as a factor of production, i.e. labour/labor (Samuelson, Nordhaus, 2010).

${ }^{2}$ For example, in Russia, which was in 57th place in the ranking of the World Economic Forum in 2017 (Latvia - in 3 7th place, the USA - in 6th place, Great Britain - in 4th place)
} 
hides first of all the fear of professional translators before competing with artificial intelligence), but to collaborate with machines. And this [ability of the "narrow elite of mankind" to collaborate with machines] is the second of the above-mentioned trends, to which the book of the futurists P. Diamandis and S. Kotler, "The Future Is Faster Than You Think: How Converging Technologies Are Transforming Business, Industries, and Our Lives" also published in January 2020 is dedicated (Diamandis, Kotler, 2020). The authors of this book came to conclusion that the growth of labour productivity and efficiency does not come so much from replacing people with machines, but from connecting machines to people, i.e. from their collaboration. P. Diamandis gives the example of BMW, which increased labour productivity by $85 \%$ when replacing automated conveyor belts with human-robot teams (Diamandis, 2020).

In such conditions, the competitive advantage of education is the transition from a computerized educational environment (which is still an innovation in many countries and educational institutions) to curricula aimed at artificial intelligence, since in many professions the ability to work with new technologies and collaborate with artificial intelligence will replace even a professional mastery. P. Diamandis and S. Kotler predict that in the next decade, humanity will produce more products than in the previous hundreds of years, and competitive advantages will be where the artificial intelligence becomes not a cognitive prosthesis, but an advanced co-worker (Diamandis, Kotler, 2020).

Based on the concept of E. Sorensen, it could be assumed that the human-machine collaboration ${ }^{3}$ creates the so-called "composite rent", which occurs when the combination of two different assets brings greater returns than each of them individually (Sorensen, 2000). Latvian researchers also note that, for example, the contribution of technological progress into increase of productivity and efficiency is greater where there are knowledgeable and welltrained people who are capable of both applying new technologies and developing them (Stepin'a, 2019), i.e. when new technologies are combined with the high-qualified human capital, the so-called effect of synergy of production factors is appearing.

Thus, by studying the factors of labour productivity and efficiency in the 21 st century (while not touching on the role of such a factor as financial resources), the authors of the article hope to give an empirical answer to the following research questions: 1) whether work as a type of activity and as a

among 137 countries in terms of the so-called "technological readiness" (World Economic Forum, 2017).

3 The term "human-robot collaboration" is used in some publications (Bauer et al., 2008; Villani et al., 2018; Directorate-General for Research and Innovation (European Commission), 2020). 
life value is really losing its significance in the modern world; 2) whether human-machine collaboration is a "motor" or a significant factor of labour productivity and efficiency.

\section{Theoretical background and methodology of the research:}

Based on scientific publications of one of the co-authors of this article (Korshenkov et al., 2019; Korshenkov, Ignatyev, 2020) productivity is defined as the ability (of production factors, of enterprises, of industries, of territories) to create as much product as possible per unit of time and is put "at the forefront" - without taking into account the efficiency of the production process - in a planned economy (Kastel's, 2019). In its turn, efficiency is a purely economic term that takes into account the amount and the costs of resources (production factors) spent in the production process.

The authors consider that the most interesting finding of modern studies on labour productivity and efficiency is the so-called "productivity paradox" (David, 1990; Brynjolfsson, 1993; Brynjolfsson, Hitt, 1995; Polak, 2014), when labour productivity stagnates even despite the introduction of new information technologies - "we see computers everywhere, but not in statistics of the productivity growth" (Brynjolfsson, Hitt, 1995, p. 183).

Until the end of the last century, labour productivity and employment were closely interconnected, for there was no "mega-gap" between financial capital and other production factors, which ["mega-gap"] gradually reduced and negated the role of labour and the scale of employment, decreasing the share of added value related to the wages of workers. That is why in the early 2000s, the "great divergence" began (Evans, Rodriguez-Montemayor, 2017): productivity continued to grow, but employment began to decline sharply, and wage growth stopped. In subsequent years, productivity also began to decline, even despite rapid technological advances - this is the productivity paradox, partly explained by mismatch of skills (Brynjolfsson, 1993; Polak, 2014), but dominantly rooted in the new role of financial capital as a strategic resource, which has its own logic of interaction with other production factors.

Productivity paradox - as many other paradoxes - corresponds to our "era of duality" (Evans, Rodriguez-Montemayor, 2017, p. 75). In the modern world, it is necessary to be able to respond to instant changes in requirements and to think about innovations and changes in the long run. Increasing competition requires the ability to do work both better and cheaper, i.e. the idea of duality implies "both one and the other at the same time" (Evans, Rodriguez-Montemayor, 2017, p. 75).

The authors suppose, that in the market economy labour productivity "merges" with its efficiency - in contrast to a planned economy, when high labour productivity could sometimes be achieved at the cost of huge amount of production factors. Thus, in the 21 st century, one can speak more about 
"labour efficient productivity" (since "unefficient productivity" is not needed in a market economy) or simply about labour productivity. Similar "connected" terms - for example, "efficient production function" or "efficiency in production" - have already been used in some scientific publications of the last century (Farrel, Fieldhouse, 1962; Carlsson, 1972, 1974), when precisely the "efficient" component of the production process began to be actively studied.

Researchers P. Doherty and J. Wilson note that the essence of the first industrial revolution was mechanization using steam technology, the second one was based on industrialization and mass production using electricity, while the third spawned automation, which made it possible to replace people with the first models of robots to perform monotonous or dangerous work. Industry 4.0, or the fourth industrial revolution, is a technological leap based on a combination of traditional automation and computerization and completely changing production sites where interconnected resources exchange information with each other (Doherty, Wilson, 2019).

The authors suppose that, for the first time in history, the world is moving toward a situation in which a minority of self-programmed, highly productive workers - people who collaborate efficiently with machines, "knowledge makers and information processors whose work is most valuable" (Kastel's, 2000, p. 45) - will feed the majority of generic replaceable workers, which "in the new world are not needed even as an object of exploitation, they simply have no place in it. Neither the ruling classes, nor society as a whole need a class that is subject to exclusion, and do not depend on it - at least in the economic sense" (Tikhonova, 2006, p. 36). One of the main challenges for this majority, D. Susskind considers "the search for a new meaning of his existence in a world where work is no longer the basis of their life" (Susskind, 2020).

\section{Empirical results and discussion on the significance of work in the modern world:}

In 2010, the European Commission adopted the Europe 2020 strategy (European Commission, 2010), which focused on improving the European economy and addressing the challenges of the next decade. One of the goals was the achievement by 2020 of at least $75 \%$ employment rate among the population of the European Union from 20 to 64 years.

In addition, EU countries have set this threshold for employment as well as their national goal. An analysis of statistics by Eurostat showed that from 2005 to 2018 there was a noticeable shift in the level of employment in the European labour market: in 2018, the employment rate among the EU-28 population from 20 to 64 years old reached $73.2 \%$, which was the highest indicator of employment rate for period starting from 2005. 
In addition, almost half of the EU member states (13 countries) achieved their national goals in terms of employment rate, i.e. marks in $75 \%$ (Eurostat, 2020). In Latvia, the level of employment rate in the 21st century according to the proportion of people employed among the population from $15^{4}$ to 64 years old - is also growing (see Figure 1).

Figure 1. The employment rate among the population of Latvia from 15 to 64 years old, \%, 2002-2019

75

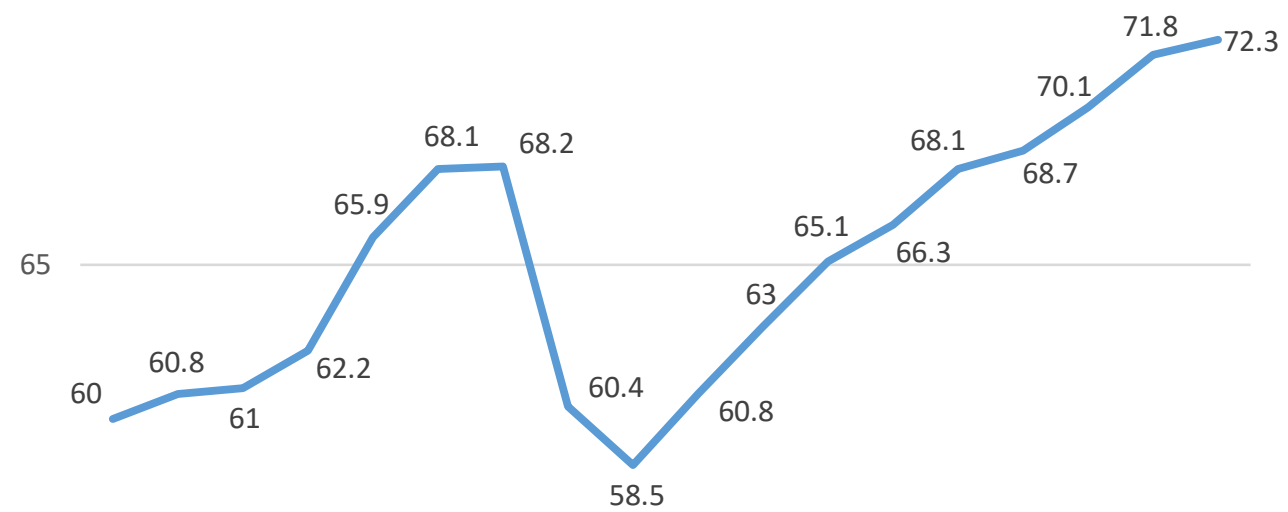

55

200220032004200520062007200820092010201120122013201420152016201720182019

Source: calculated by the authors according to the Central Statistical Bureau of Latvia, 2020a.

Despite the increase in employment rate in the EU as a whole and in Latvia in particular (from $60.0 \%$ in 2002 to $72.3 \%$ in 2019 - see Figure 1), the authors also found a lot of empirical evidence that the work as a type of activity and as a life value is losing its significance in the modern world. For example, in Latvia such a group of "employed" who actually do not work is constantly present and over the past period of the 21st century its unit weight has increased (from $4.2 \%$ of all employed in 2002 to $7.3 \%$ in 2019 - see Figure 2). In addition, over the 21 st century, the proportion of people working more than 40 hours per week has been rapidly decreasing in Latvia - from $33 \%$ of all employed in 2002 to 5\% in 2019 (see Figure 2).

${ }^{4}$ In Latvia's official statistics, the age group of 20 to 64 years is not allocated, as in the EU statistics. 
Figure 2. The number of hours actually worked per week, $\%$ of employees for each group of hours, 2002-2019

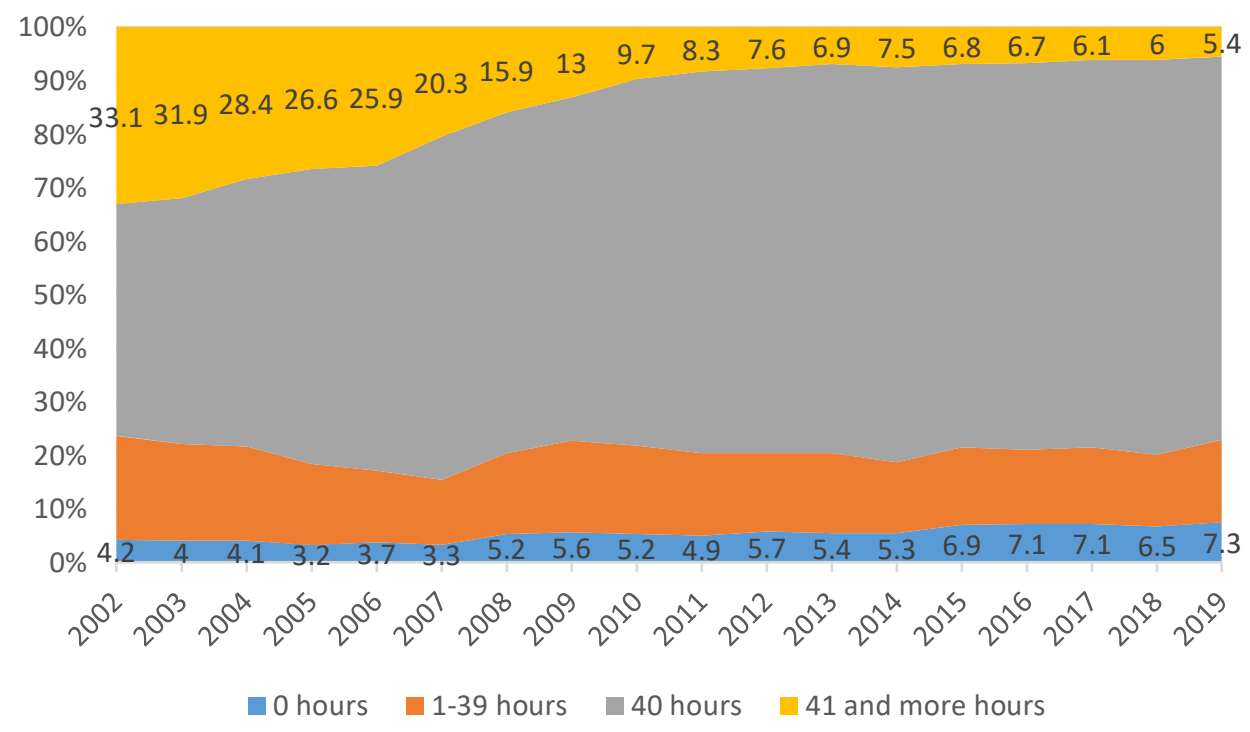

Source: calculated by the authors according to the Central Statistical Bureau of Latvia, 2020b.

In addition, the results of the labour force survey in Latvia show that among people working part-time, the proportion of those who indicate their unwillingness to work full-time as a reason for underemployment is quite large (see Figure 3).

Figure 3. The proportion of those part-time workers of Latvia, who mentioned as a reason "I do not want to work full-time", \% of all part-time workers, 2002-2019*

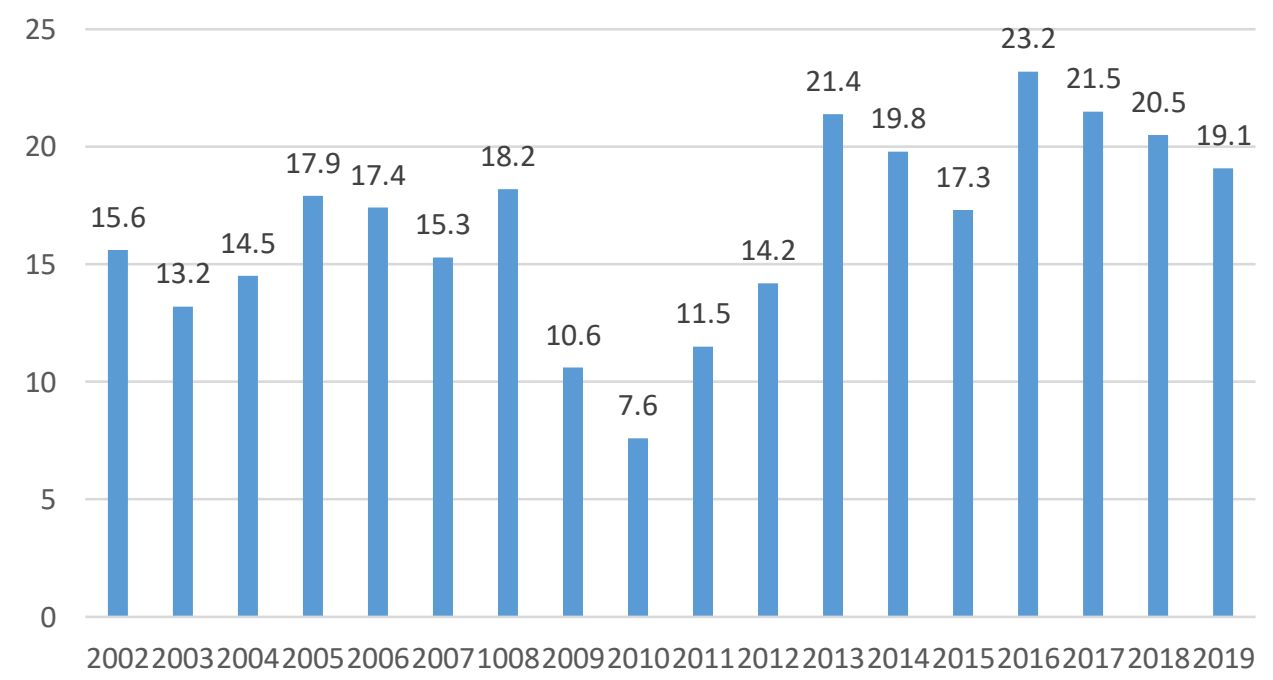

Source: calculated by the authors according to Central Statistical Bureau of Latvia, 2020c.

* 2002-2011 - recalculation according to the results of the 2011 census 
Since over the past years of the 21st century, the proportion of those who do not want to work full-time in Latvia has fluctuated in the direction of increasing or decreasing, the authors applied two special methods to determine the general direction of the trend: 1) the method of minima and maxima; 2) the moving average method (period -3 years).

Results of the analysis by the method of minima and maxima showed that each subsequent minimum $(13.2 ; 15.3 ; 7.6 ; 17.3 ; 19.1$ - see Figure 3$)$ and each subsequent maximum $(17.9 ; 18.2 ; 21.4 ; 23.2$ - see Figure 3$)$ except for crisis years was higher than the previous one, i.e. unwillingness to work fulltime among Latvians in the 21st century as a whole has an upward trend.

In its turn, the results of applying the moving average method with a period of 3 years showed that in the period after the global financial crisis - as well as before it - the trend was upward:

- 2002-2004 - 14.4\% (annually in average) of part-timers indicated that they did not want to work full-time;

- 2005-2007-16.9\%;

$-2008-2010-12.1 \%$;

$-2011-2013-15.7 \%$

- 2014-2016-20.1\%;

- 2017-2019-20.4.

Thus, over the past decade, the unwillingness to work full-time in Latvia has been growing.

An analysis of the results of the World Values Survey also allows the authors to conclude that the perception of work as a significant life value in the modern world is gradually but steadily declining (see Figure 4). 
Figure 4. The proportion of those who consider work a very important life value, $\%$ of the total number of respondents, China, Sweden and the USA, 1990-2014

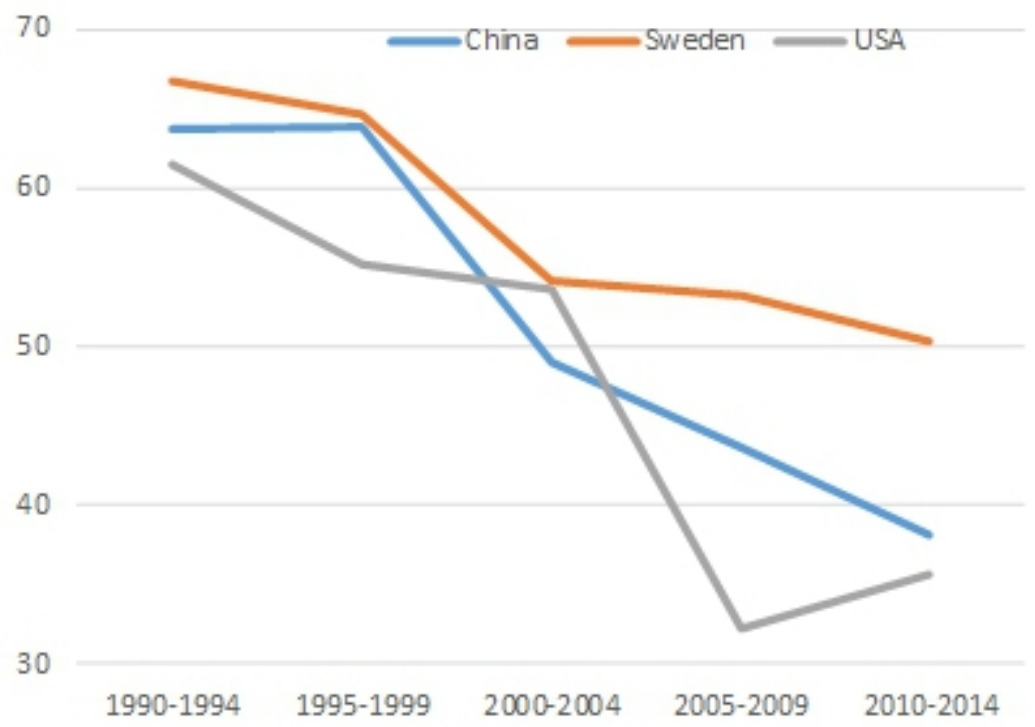

\begin{tabular}{|l|l|l|l|l|l|}
\hline Country & $\mathbf{1 9 9 0 - 1 9 9 4}$ & $\mathbf{1 9 9 5 - 1 9 9 9}$ & $\mathbf{2 0 0 0 - 2 0 0 4}$ & $\mathbf{2 0 0 5 - 2 0 0 9}$ & $\mathbf{2 0 1 0 - 2 0 1 4}$ \\
\hline China & 63.8 & 63.9 & 49.0 & 43.7 & 38.1 \\
\hline Sweden & 66.8 & 64.6 & 54.1 & 53.2 & 50.3 \\
\hline USA & 61.5 & 55.2 & 53.6 & 32.2 & 35.6 \\
\hline
\end{tabular}

Source: calculated by the authors according to the Institute for Comparative Survey Research, 2020.

By the example of three "worlds" - Asian (China), European (Sweden) and North American (USA) - the authors showed that over the 21st century (and in the USA this process began even earlier), the proportion of those people who consider work a very important value in their lives is constantly declining. The number of work's connoisseurs in the USA has decreased especially strongly - almost by half - over 25 years (see Figure 4).

The results of studying the changes in the amount of real time people spend on work in different countries of the world in the long historical perspective - from the time of the industrial revolution at the end of the 19th century - showed that the number of hours worked began to decline steadily after the industrial revolution, and current employees work 20, or even 30 hours less than people worked weekly at the end of the 19th century (Roser, 2020).

The main factor in this global long-term stable decrease in the number of hours worked is considered to be an increase in labour productivity - today

5 The results of the "seventh wave" of the World Values Survey - for 2017-2020 - will be freely available in July 2020 (Institute for Comparative Survey Research, 2020). 
fewer hours work in the countries with the highest GDP per hour worked - for example, in Ireland an average working time of employees in 2017 was 1746 hours with an average labour productivity of $\$ 99$ per hour, but in China 2174 hours with an average labour productivity of \$ 11 per hour (Roser, 2020).

The fact that, thanks to information and communication technologies, people can do work "from home" in the format of full, part or additional employment, stimulates the emergence of new lifestyles. The Scandinavians, with their clear focus on the result of work, are furthest along this path. They spend less time in the office compared to their counterparts in other countries and return home at about $4 \mathrm{pm}$ to spend time with their children; they take extra days off to look after the garden or go to the gym. This is an example of a society that has managed to master technology in order to increase labour productivity (Evans, Rodriguez-Montemayor, 2017).

\section{Empirical results and discussion on determinants of labour productivity:}

In this section of the article, the authors try to answer the second research question posed in the Introduction to the article: is the humanmachine collaboration a "motor" or a factor of labour productivity?

Y. Harari claims that Industry 4.0 is qualitatively changing the "landscape" of production factors, "lowering" a worker to one level with other factors included in a common communication network and shared information equally (Harari, 2016). This equal exchange between production factors founds a new reality in which a human worker gradually loses a dominant position in the production and information network and loses also his/her productivity if the purposeful efforts to harmonize all factors of the production system are absent. To prevent this [loss of a human worker's dominant position], not only a "wise man" (Homo Sapiens) is needed, but a "godlike man" (Homo Deus) (Harari, 2016). Y. Harari argues that we need a new education system aimed at the formation (the authors believe - support) of people with the "God"s spark", talented.

The international company KUKA has developed the first robot approved for cooperation with humans - KUKA LBR iiwa. It uses intelligent automatic control technology, high-precision sensors and modern software technology, providing completely new collaborative solutions.

Robots intended for cooperation with humans, such as LBR iiwa, due to mobile platforms, for example, KUKA flexFELLOW, are not tied to the concrete location and can perform different functions. Thus, they can be used in the place and for the purpose that is required for a particular production process, for example, at BMW in Dingolfing, where previously workers had to lift themselves and install heavy bevel gears for the front axle gearbox. Now they work together with the sensitive robot-colleague LBR iiwa in a small area - completely without protective fences and in their usual environment. In the 
modern scientific literature, the terms "integrated intelligence" (Lichtenthaler, 2020) and "cooperative intelligence" (Wilson, Daugherty, 2018) are also used to analyze the human-machine collaboration (Wilson, Daugherty, 2018) with the purpose of designating a new phenomenon in which people and artificial intelligence "are joining forces" (Wilson, Daugherty, 2018).

The most difficult in the process of empirical study of the humanmachine collaboration as a factor in the growth of labour productivity is its [human-machine collaboration] empirical interpretation and measurement. The authors suggest to apply two indicators simultaneously as an empirical basis for measuring the level of human-machine collaboration in the world countries (two at once - for more reliable assessment): "ICT adoption" and "digital skills among population", measured by the World Economic Forum within the Global Competitiveness Report 2018 applying the scale from 0 to 100 scores (World Economic Forum, 2018).

Although the selected indicators do not directly indicate the level of human-machine collaboration in a country, a high score for these two indicators together still confirms a country's serious potential in this area. Thus, the authors suppose that ICT adoption and digital skills among population of a country is not a sufficient but necessary condition or base for human-machine collaboration, and in countries where these indicators - "ICT adoption" and "digital skills among population" - have low scores, is not possible even to think about the real possibility of human-machine collaboration.

In its turn, for empirical measurement of labour productivity within this research the authors have been chosen the indicator provided for more than 100 countries of the world by the Business School for the World with partner organizations in their annual report "The Global Talent Competitiveness Index 2019": "labour productivity per employee" (Indicator 5.1.4.), which means labour productivity per person employed and calculated in two ways - in absolute meanings (USD per person for a year) as well as weighted score from 0 to 100 (100 has a country with maximal absolute meaning, 0 has a country with minimal one) (INSEAD et al., 2019). The authors applied the weighted scores for further empirical analysis, because estimated factors of labour productivity (see Figure 5) are also measured by weighted score from 0 to 100 .

The authors worked out the model of empirical investigation of the level of human-machine collaboration as a factor of labour productivity (see Figure 5). The authors consider it would be worthwhile for comparison to introduce into the analysis two additional "background" indicators characterizing the education system in a country, namely: "mean years of schooling" and "quality of vocational training" (World Economic Forum, 2018). 
Figure 5. Model of empirical investigation of the level of human-machine collaboration as a factor of labour productivity

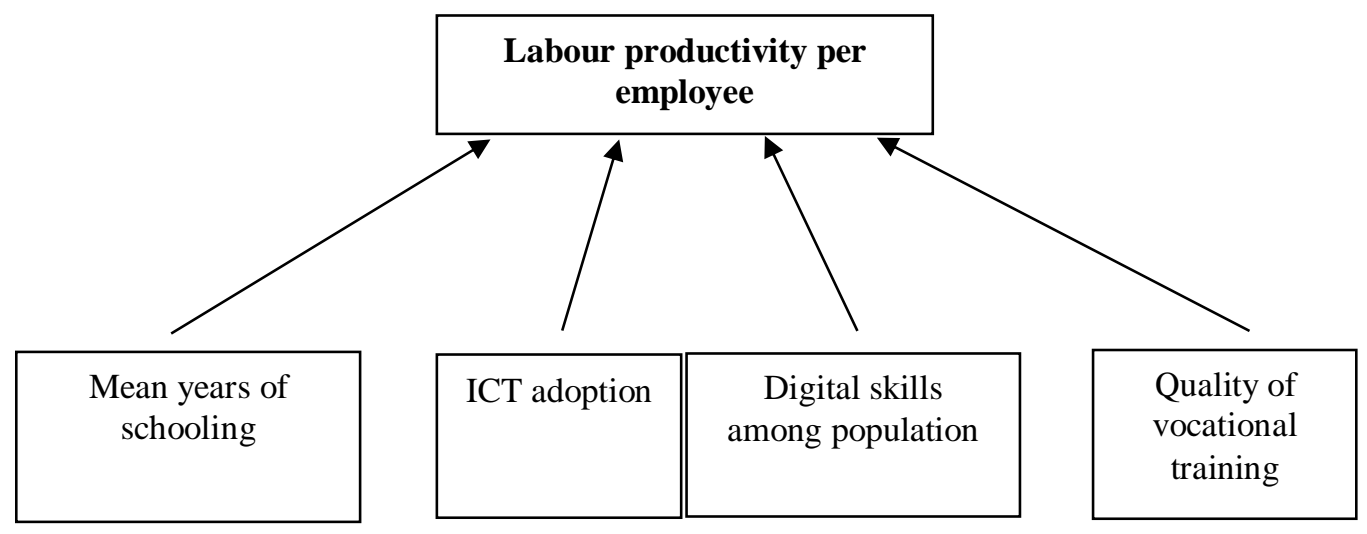

\begin{tabular}{|c|c|c|}
\hline \multicolumn{3}{|c|}{$\begin{array}{l}\text { Levels of empirical analysis } \\
\text { Global level: the world's countries for which empirical data are available for all selected } \\
\text { indicators }\end{array}$} \\
\hline $\begin{array}{l}\text { Countries with a } \\
\text { high potential* of } \\
\text { human-machine } \\
\text { collaboration }\end{array}$ & $\begin{array}{l}\text { The indicator "ICT adoption" } \\
\text { in the country has higher } \\
\text { score than the average } \\
\text { meaning in a sample of } \\
\text { countries }\end{array}$ & $\begin{array}{l}\text { The indicator "digital skills } \\
\text { among population" in the } \\
\text { country has higher score than the } \\
\text { average meaning in a sample of } \\
\text { countries }\end{array}$ \\
\hline $\begin{array}{l}\text { Countries with a } \\
\text { low potential of } \\
\text { human-machine } \\
\text { collaboration }\end{array}$ & $\begin{array}{l}\text { The indicator "ICT adoption" } \\
\text { in the country has lower } \\
\text { score than the average } \\
\text { meaning in a sample of } \\
\text { countries }\end{array}$ & $\begin{array}{l}\text { The indicator "digital skills } \\
\text { among population" in the } \\
\text { country has lower score than the } \\
\text { average meaning in a sample of } \\
\text { countries }\end{array}$ \\
\hline
\end{tabular}

Source: elaborated by the authors.

* the term "potential" is also used in EU publications (Directorate-General for Research and Innovation (European Commission), 2020) and in scientific publications (Pitso, 2019)

Note - list of indicators:

- "labour productivity per employee", weighted score from 0 to 100, 2018 (INSEAD et al., 2019);

- "mean years of schooling", weighted score from 0 to 100, 2018 (World Economic Forum, 2018);

- "ICT adoption", weighted score from 0 to 100, 2018 (World Economic Forum, 2018);

- "digital skills among population", weighted score from 0 to 100, 2018 (World Economic Forum, 2018);

- "quality of vocational training", weighted score from 0 to 100, 2018 (World Economic Forum, 2018).

To empirically confirm the assumption that in the 21 st century, humanmachine collaboration is a statistically significant factor of labour productivity, the authors conducted a regression (on a global level) or 
correlation (on a country group level) analysis as well as a comparison of means within each level of empirical analysis:

1) the global level (103 countries): the object of empirical analysis is the world's countries for which empirical data are available for all selected indicators;

2) countries with a high potential of human-machine collaboration (44 countries): the object of empirical analysis is those countries of the world in which both the indicator "ICT adoption" and the indicator "digital skills among population" are higher than the average meaning of these indicators in a sample of countries, i.e. the value of the indicator "ICT adoption" is higher than 56.1, and simultaneously the value of the indicator "digital skills among population" is higher than 56.9;

3) countries with a low potential of human-machine collaboration (44 countries): the object of empirical analysis is those countries of the world in which both the indicator "ICT adoption" and the indicator "digital skills among population" are higher than the average meaning of these indicators in a sample of countries, i.e. the value of the indicator "ICT adoption" is lower than 56.1, and simultaneously the value of the indicator "digital skills among population" is lower than 56.9.

In order to determine statistically significant factors of labour productivity at the global level, i.e. in the sample of 103 countries, the authors performed a regression analysis using the Stepwise Variable Inclusion method with "participation" of all the indicators shown in Figure 5 and obtained the following linear regression equation as the result of empirical data analysis for 2018 (World Economic Forum, 2018; INSEAD et al., 2019), conducted using the IBM SPSS Statistics software application for processing and analyzing statistical data:

$\mathrm{y}=-21.731+0.934 \mathrm{x}_{2}$

where:

$\mathrm{y}$ - labour productivity per employee;

$\mathrm{x}_{2}-\mathrm{ICT}$ adoption.

Excluded (non-significant) variables:

$\mathrm{x}_{1}$ - mean years of schooling;

$\mathrm{x}_{3}$ - digital skills among population;

$\mathrm{x}_{4}-$ quality of vocational training.

The result of the regression analysis presented in Equation 1 shows that out of all four potential factors of labour productivity in the modern world taken for analysis, only the level of application of ICT in a country, i.e. the indicator "ICT adoption", statistically significantly increased the labour productivity in 2018 (see Equation 1). 
At first glance, this contradicts the above-mentioned thesis about the productivity paradox, in which "we see computers everywhere, but not in statistics of the productivity growth" (Brynjolfsson, Hitt, 1995, p. 183). But if to combine two indicators - "ICT adoption" and "digital skills among population" - into one variable by calculating the arithmetic mean between them, the following linear regression equation is got:

$\mathrm{y}=-38.809+1.230 \mathrm{x}_{2 / 3}$

where:

$\mathrm{y}$ - labour productivity per employee;

$\mathrm{x}_{2 / 3}$ - arithmetic mean between the indicators "ICT adoption" and "digital skills among population".

Excluded (non-significant) variables:

$\mathrm{x}_{1}$ - mean years of schooling;

$\mathrm{x}_{4}-$ quality of vocational training.

A rather significant increase in the $\beta$-coefficient - from 0.934 in Equation 1 to 1.230 in Equation 2 - when two indicators are combined (which the authors consider a necessary condition or base for human-machine collaboration), indicates that the stimulating effect of ICT on labour productivity in the country is significantly enhanced when simultaneously there is a high level of digital skills among population in this country, which is consistent with the explanation of the productivity paradox through mismatch of skills (Brynjolfsson, 1993; Polak, 2014). In addition, the result of the regression analysis also confirms the aforementioned conclusion by Latvian researchers that the contribution of technological progress to increasing productivity is greater where there are people who are capable of both applying new technologies and developing them (Stepin'a, 2019).

In its turn, a comparative analysis of countries with high and low potential of human-machine collaboration showed that in the first group of countries the average labour productivity per employee, measured in scores from 0 to 100 (INSEAD et al., 2019), in 2018 was 47.2 scores, and in the group of countries with a low potential of human-machine collaboration -12.8 scores, and this difference is statistically significant ( $\mathrm{p}$-value $=0.000)$, which also confirms the result of the regression analysis that the potential of humanmachine collaboration (empirically interpreted as the arithmetic mean between "ICT adoption" and "digital skills among population") in the modern world is statistically significant factor in labour productivity.

The following Table presents the results of comparing the average values of the investigated indicators and on the correlation between them and labour productivity in countries with a high and a low potential of humanmachine collaboration. 
Table 1. Comparison of the average values of the investigated indicators and their interconnection with labour productivity in countries with

a high and a low potential of human-machine collaboration, 2018

\begin{tabular}{|c|c|c|c|c|}
\hline \multirow{2}{*}{$\begin{array}{l}\text { Analyzed } \\
\text { indicators }\end{array}$} & \multicolumn{2}{|c|}{$\begin{array}{l}\text { Countries with a high potential } \\
\text { of human-machine } \\
\text { collaboration, } 44 \text { countries }\end{array}$} & \multicolumn{2}{|c|}{$\begin{array}{l}\text { Countries with a low potential } \\
\text { of human-machine } \\
\text { collaboration, } 37 \text { countries }\end{array}$} \\
\hline & $\begin{array}{l}\text { The average } \\
\text { value of the } \\
\text { indicator in } \\
\text { the sample of } \\
\text { countries, } \\
\text { scores from } 0 \\
\text { to } 100\end{array}$ & $\begin{array}{l}\text { Correlation of } \\
\text { this indicator } \\
\text { with labour } \\
\text { productivity, } \\
\text { Pearson } \\
\text { correlation } \\
\text { coefficient }\end{array}$ & $\begin{array}{l}\text { The average } \\
\text { value of the } \\
\text { indicator in a } \\
\text { sample of } \\
\text { countries, } \\
\text { scores from } 0 \\
\text { to } 100\end{array}$ & $\begin{array}{l}\text { Correlation of } \\
\text { this indicator } \\
\text { with labour } \\
\text { productivity, } \\
\text { Pearson } \\
\text { correlation } \\
\text { coefficient }\end{array}$ \\
\hline $\begin{array}{l}\text { Mean years of } \\
\text { schooling }\end{array}$ & 78.0 & $\begin{array}{l}0.230 \\
p=0.133\end{array}$ & 47.0 & $\begin{array}{l}0.598 * * \\
\mathrm{p}=0.000\end{array}$ \\
\hline ICT adoption & 72.2 & $\begin{array}{l}0.389 * * \\
p=0.009\end{array}$ & 37.4 & $\begin{array}{l}0.678 * * \\
p=0.000\end{array}$ \\
\hline $\begin{array}{l}\text { Digital skills } \\
\text { among } \\
\text { population }\end{array}$ & 67.8 & $\begin{array}{l}0.556^{* *} \\
\mathrm{p}=0.000\end{array}$ & 44.6 & $\begin{array}{l}0.364^{*} \\
p=0.027\end{array}$ \\
\hline $\begin{array}{l}\text { Quality of } \\
\text { vocational } \\
\text { training }\end{array}$ & 62.5 & $\begin{array}{l}0.515 * * \\
p=0.000\end{array}$ & 44.1 & $\begin{array}{l}-0.048 \\
p=0.778\end{array}$ \\
\hline
\end{tabular}

Source: calculated and compiled by the authors according to INSEAD et al., 2019 and the World Economic Forum, 2018 using the IBM SPSS Statistics software application for processing and analyzing statistical data.

* statistically significant correlation (with $95 \%$ probability)

** statistically significant correlation (with $99 \%$ probability)

Note: differences in the average values of all analyzed indicators between the two groups of countries are statistically significant $-\mathrm{p}$-values for all four indicators are 0.000 .

Comparative data presented in Table 1 show that in the 21st century not always those factor, which is well developed in a country, really stimulates labour productivity - for example, a group of countries with a high potential of human-machine collaboration (and with relatively high labour productivity) has the high average value of the indicator "mean years of schooling" (78 scores versus 47 in a group of countries with a low potential of humanmachine collaboration - see Table 1), but in this group of countries, the duration of schooling does not correlate with labour productivity $(r=0.230, p$ $=0.133-$ see Table 1) - in contrast to the group of countries with a low potential of human-machine collaboration, where the duration of schooling is statistically significantly and quite strong correlates with labour productivity $(\mathrm{r}=0.598, \mathrm{p}=0.000-$ see Table 1$)$. In its turn, the quality of vocational training is much higher in itself, and is interconnected with labour productivity exactly in the group of countries with a high potential of human-machine collaboration (see Table 1). 
As for indicators indicating the potential of human-machine collaboration, the results of a comparative analysis show that in countries with a high potential it is currently more important to develop digital skills of the population, since they are more interrelated with labour productivity than the ICT adoption in these countries (see Table 1) - probably because in countries with a high potential of human-machine collaboration, the economic law of diminishing marginal productivity of production factors (namely, marginal productivity of ICT with a constant level of digital skills of workers) begins to apply, which, according to the authors, is also the reason for the productivity paradox in these countries.

At the same time, in countries with a low potential of human-machine collaboration, the digital skills of the population are much weaker than the ICT adoption correlates with labour productivity $(0.364$ and 0.678 , respectively see Table 1), which, according to the authors, indicates that this group of countries is still at the stage of ICT implementation and has not yet encountered a productivity paradox.

\section{Disputable example of human-machine collaboration in Latvia:}

In Latvia, which, according to the methodology of this research (see the model of empirical investigation of the level of human-machine collaboration as a factor of labour productivity in Figure 5), belongs to a group of countries with a high potential of human-machine collaboration, ${ }^{6}$ there are also noteworthy achievements in this area - for example, new neural machine translation technology (Birzin'sh, 2019). The Latvian company "Tilde" together with researchers from the University of Latvia has managed to create better machine translation technologies than such world-famous companies as "Google" and "Microsoft". This achievement was one of the most significant in Latvian science in 2018 according to the experts of the Latvian Academy of Sciences (Latvian Academy of Sciences, 2018).

R. Skadin'sh, Research and Development Director of SIA "Tilde", points out: "Back in the late 1990s we tried to describe the translation process with grammar rules. Nowadays, artificial intelligence technologies learn from examples. We give millions of sentences in Latvian with translations from English, and then the computer analyzes these examples. learning regularities and grammar itself'. Translators only have to check whether the text has been translated adequately and correct the details (Birzin'sh, 2019).

The authors of the article believe that training such a technology and, more importantly, collaboration with artificial intelligence in order to increase the productivity of translation work is practically the only main task of higher

${ }^{6}$ Latvia has a rather high value of the indicator "ICT adoption" - 80.4, but not too high, although it is higher than the average in the world, the value of the indicator "digital skills among population" - 62.0 (World Economic Forum, 2018). 
education in the field of translation, which is currently not implemented in the framework of educational programs of translation specialties of Latvia's universities and higher schools (Daugavpils University, 2020; Rezekne Technology Academy, 2020; Ventspils University, 2020 and others), including the University of Latvia (University of Latvia, 2020).

Universities and higher schools of Latvia train translators in accordance with the State Standard for the profession of translator in Latvia (Cabinet of Ministers of the Republic of Latvia, 2010), which indicates that Latvia's higher education is in the so-called "trap" - in the context of training specialists who are able to not compete, but to collaborate with artifical intelligence (i.e., in the case of translation work, to help machines in their learning of better way to help people to translate). In terms of neo-institutional theory a "trap" is defined as "an inefficient stable norm that has a selfsupportive nature" (Polterovich, 1998, p. 34).

\section{Conclusion}

As the main result of this research, the authors provide an empirical answer to the research questions, pointed our within Introduction of the article: 1) Whether work as a type of activity and as a life value is really losing its significance in the modern world? 2) Whether human-machine collaboration is a "motor" or a significant factor of labour productivity?

The capacity of the authors to answer these research questions is limited by availability of related statistical or sociological data as well as by the empirical interpretation and measurement of the concept "human-machine collaboration". For instance, the answer of the first question is based on the data of the World Values Survey, which are available for separate countries, not for a world as a whole (the authors have chosen China, Sweden and USA as representatives of different parts of the world). In its turn, some specific data about reasons of the part-time employment and dynamics of number of hours really worked per week are available just about Latvia. As for empirical interpretation and measurement of "human-machine collaboration", the authors have measured this by two indicators which show the potential of a country in human-machine collaboration: digital skills of the population and ICT adoption. The random of countries, where the role of human-machine collaboration as a significant factor of labour productivity has been tested, is limited by 103 countries of the world about which data on digital skills of the population and ICT adoption are available.

Based on the empirical analysis limited by the above-mentioned restrictions, the authors can conclude that, firstly, work as a type of activity and as a life value is really losing its significance. Despite the increase in employment rate in the EU as a whole in Latvia, for instance, it is constantly present and over the past period of the 21 st century increases - from $4.2 \%$ in 
2002 to $7.3 \%$ in 2019 - the proportion of such a group of "employed" who actually do not work. In addition, over the 21 st century, the proportion of people working more than 40 hours per week has been rapidly decreasing in Latvia - from 33\% of all employees in 2002 to 5\% of all employees in 2019. Among Latvians working part-time, there is a rather large proportion of those who, as a reason for underemployment, indicate their unwillingness to work full-time, and over the past decade, the unwillingness to work full-time in Latvia has been growing. An analysis of the results of the World Values Survey also allows the authors to conclude that the perception of work as a significant life value in the modern world is gradually, but steadily decreasing.

Based on the empirical analysis limited by the above-mentioned restrictions, the authors can conclude that, secondly, human-machine collaboration is a significant factor of labour productivity. The results of the regression analysis show that the stimulating effect of ICT on labour productivity in the world's countries is significantly enhanced while the country has a high level of digital skills of the population.

In addition, a comparative analysis showed that in the 21 st century not always those factor, which is well developed in a particular country, really stimulates its labour productivity - for example, a group of countries with a high potential of human-machine collaboration (and relatively high labour productivity) has also a high value of the duration of schooling, but in this group of countries the duration of schooling does not correlate with labour productivity. So, in countries with a high potential of human-machine collaboration, including in Latvia, it is important to develop digital skills of the population, since they are more closely interconnected with labour productivity than the ICT adoption; in its turn, in countries with a low potential of human-machine collaboration, digital skills of the population are significantly less correlated with labour productivity than the ICT adoption.

\section{References:}

1. Adler, G., Duval, R. A., Furceri, D., Kilic Celik, S., Koloskova, K., \& Poplawski-Ribeiro, M. (Eds.). (2017). Gone with the headwinds: Global productivity. Retrieved from: https://www.imf.org/en/Publications/Staff-DiscussionNotes/Issues/2017/04/03/Gone-with-the-Headwinds-GlobalProductivity-44758.

2. Basu, S., \& Kimball, M. (1997). Cyclical productivity with unobserved input variation. NBER Working Paper No. 5915. Cambridge, MA: National Bureau of Economic Research.

3. Bauer, A., Wollherr, D., \& Buss, M. (2008). Human-robot collaboration: A survey. Humanoid Robotics, Vol. 5, pp. 47-66. 
4. Birzin'sh, U. (2019). Latviia izstrada iaunu neironu mashintulkoshanas tehnologiiu. Retrieved from: https://www.lsm.lv/raksts/dzive--stils/tehnologijas-un-zinatne/latvijaizstrada-jaunu-neironu-masintulkosanas-tehnologiju.a305974/. (In Latvian)

5. Brynjolfsson, E. (1993). The productivity paradox of information technology: Review and assessment. Communications of the ACM. Retrieved from: http://ccs.mit.edu/papers/CCSWP130/ccswp130.html.

6. Brynjolfsson, E., \& Hitt, L. (1995). Information technology as a factor of production: The role of differences among firms. Economics of Innovation and New Technology, Vol. 3, pp. 183-200.

7. Cabinet of Ministers of the Republic of Latvia. (2010). Tulkotaia profesiias standarts. 2.pielikums Ministru kabineta 18.05.2010.g. noteikumiem Nr.461. (In Latvian)

8. Carlsson, B. (1972). The measurement of efficiency in production: An application to Swedish manufacturing industries 1968. The Swedish Journal of Economics, Vol. 74, No. 4, pp. 468-485.

9. Carlsson, B. (1974). The measurement of efficiency in production: A reply. The Swedish Journal of Economics, Vol. 76, No. 2, pp. 255-258.

10. Central Statistical Bureau of Latvia. (2020a). Table NB050c: Employed and employment rate by age group, sex and quarter. Retrieved from: https://data1.csb.gov.lv/pxweb/en/sociala/sociala__nodarb_nodarb_ _isterm/NB050c.px/.

11. Central Statistical Bureau of Latvia. (2020b). Table NB120c: Employed by number of hours actually worked per week by quarter. Retrieved from: http://data1.csb.gov.lv/pxweb/en/sociala/sociala_nodarb_nodarb_ isterm/NB120c.px/.

12. Central Statistical Bureau of Latvia. (2020c). NB111c: Part-time work reason by quarter. Retrieved from: https://data1.csb.gov.lv/pxweb/en/sociala/sociala__nodarb_nodarb_ isterm/NB111c.px.

13. Daugavpils University. (2020). Akademiska magistra studiiu programma "Tulks, tulkotays". Retrieved from: https://du.lv/studijas/studiju-programmas/profesionala-magistrastudiju-programmas/tulks-tulkotajs/. 
14. Daugherty, P. R., \& Wilson, H. J. (2018). Human + Machine: Reimagining work in the age of AI. Harvard Business Review Press.

15. David, P. (1990). The dynamo and the computer: An historical perspective on the modern productivity paradox. American Economic Review, Vol. 80, No. 2, pp. 355-361.

16. Diamandis, P. H. (2020). For a bright future of work, we must get better at collaborating with machines. SingularityHub. Retrieved from: https://singularityhub.com/2020/02/27/for-a-bright-future-of-workwe-must-get-better-at-collaborating-with-machines/.

17. Diamandis, P. H., \& Kotler, S. (2020). The future is faster than you think: How converging technologies are transforming business, industries, and our lives. Simon \& Schuster Audio.

18. Directorate-General for Research and Innovation (European Commission). (2020). Unlocking the potential of industrial humanrobot collaboration. Publications Office of the EU. Retrieved from: https://op.europa.eu/en/publication-detail/-/publication/407d1cee5225-11ea-aece-01aa75ed71a1/language-en.

19. European Commission. (2010). EUROPE 2020: A European strategy for smart, sustainable and inclusive growth. Retrieved from: https://ec.europa.eu/eu2020/pdf/COMPLET\%20EN\%20BARROSO $\% 20 \% 20 \% 20007 \% 20-\% 20$ Europe\%202020\%20$\% 20$ EN\%20version.pdf.

20. Eurostat. (2020). Employment rates and Europe 2020 national targets. Statistics Explained. Retrieved from: https://ec.europa.eu/eurostat/statisticsexplained/index.php/Employment_rates_and_Europe_2020_national _targets\#Persistent_increase_of_the_employment_rate_at_EU_level.

21. Evans, P., \& Rodriguez-Montemayor, E. (2017). Are we prepared for the talent overhaul induced by technology? A GTCI research commentary. In B. Lanvin, P. Evans (Eds.). Global Talent Competitiveness Index 2017: Talent and technology (pp. 67-84). France: Fontainebleau.

22. Farrel, M., \& Fieldhouse, M. (1962). Estimating efficient production functions under increasing returns to scale. Journal of the Royal Statistical Society, Series A, No. 125, pp. 252-267.

23. Giddens, A. (1989). Sociology. 1st Edition. Great Britain: Polity Press.

24. Harari, Y. N. (2016) Homo Deus. A brief history of tomorrow. Harvill Secker.

25. INSEAD (The Business School for the World), the Adecco Group, Tata Communications. (2019). The Global Talent Competitiveness 
Index 2019: Entrepreneurial talent and global competitiveness. B. Lanvin, P. Evans (Eds.). France: Fontainebleau.

26. Institute for Comparative Survey Research. (2020). World Values Survey.

Retrieved from: http://www.worldvaluessurvey.org/WVSOnline.jsp.

27. International Monetary Fund. (2016). How to get back on the fast track. Regional Economic Issues, Central, Eastern and Southeastern Europe, Chapter 2.

28. Kasyanovs I. (2019) Produktivitates dazhadas nokrasas un nakotnes izaicinaiumi ilgtspeyigas augsmes konteksta. I. Shteinbuka (Zin. red.). Produktivitates celshana: tendences un nakotnes izaicinaiumi. Riga: LU Akademiskais apgads, 31.-42. lpp. (In Latvian)

29. Kastel's M. (2019) Informatsionnaia epokha. Ekonomika, obshchestvo i kultura. Moskva: Litres. (In Russian)

30. Korshenkov, E., Ignatyev, S., \& Dembovskiy, V. (2019). Teoreticheskoie i metodologicheskoie obosnovaniie izucheniia proizvoditel'nosti i produktivnosti v regional'noi ekonomike. Socialo zinatniu vestnesis, Nr. 2(29), s. 25-64. (In Russian)

31. Korshenkov, E., \& Ignatyev, S. (2020) Empirical interpretation and measurement of the productivity and efficiency of regions: the case of Latvia. Insights into Regional Development, Vol. 2, No. 2, pp. 549561.

32. Krugman, P. (1997). The age of diminished expectations. U.S. economic policy in the 1990s. 3rd Edition. Cambridge, Massachusetts, London: MIT Press.

33. Latvian Academy of Sciences. (2018). Nozimigakie sasniegumi zinatne 2018. gada. Retrieved from: http://www.lza.lv/images/stories/Pasakumi/SASNIEGUMI_2018_LV .pdf. (In Latvian)

34. Lichtenthaler, U. (2020). Integrated intelligence: Combining human and artificial intelligence for competitive advantage. Campus Verlag.

35. McMillan, M., \& Rodrik, D. (2011). Globalization, structural change and productivity growth. NBER Working Papers 17143. Cambridge, MA: National Bureau of Economic Research.

36. Mosselmans, B., \& White, M. (2001). Collected economic writings of W.S. Jevons. London: Palgrave Macmillan.

37. OECD (Organisation for Economic Co-operation and Development). (2015). The future of productivity. Paris: OECD publishing. 
38. Pitso, T. (2019). Shared futures: An exploration of the collaborative potential of intelligent machines and human ingenuity in co-creating value. Retrieved from: https://www.intechopen.com/books/towardsuper-creativity-improving-creativity-in-humans-machines-andhuman-machine-collaborations/shared-futures-an-exploration-of-thecollaborative-potential-of-intelligent-machines-and-human-ingen.

39. Polak, P. (2014). The productivity paradox: A meta-analysis. IES Working Paper No. 28/2014. Prague: Charles University in Prague, Institute of Economic Studies (IES).

40. Polterovich, V. I. (1998). Institucional'niie lovushki i ekonomicheskiie reformi. Moskva: Rossiyskaia ekonomicheskaia shkola. (In Russian)

41. Rezekne Academy of Technologies. (2020). Studiiu programma: Lietishkia komunikaciia un tulkoshana. Programmas saturs. Retrieved from:

https://www.rta.lv/rta_istenotas_studiju_programmas?sp_id=14. (In Latvian)

42. Roser, M. (2020). Working hours. OurWorldInData.org. Retrieved from: https://ourworldindata.org/working-hours.

43. Samuelson, P., \& Nordhaus, W. (2010). Economics. 19th Edition. McGraw-Hill/Irwin.

44. Skadin'a, I., Veisbergs, A., Vasilyevs, A., Gornostaia, T., Keisha, I., \& Rudzite, A. (2012). The Latvian language in the digital age. Berlin, Heidelberg: Springer-Verlag.

45. Skvortsova, O. V., \& Tikhonova, Ie. V. (2016). Problemy i preimuschestva avtomatizirovannogo i mashinnogo perevodov. Molodoi uchonii, №9 (113), Chast 13, s. 1287-1289. (In Russian)

46. Sorensen, A. B. (2000). Toward a sounder basis for class analysis. American Journal of Sociology, Vol. 105, No. 6, pp. 1523-1558.

47. Stepin'a, I. (2019). Produktivitate: kapec butiska Latviiai un Latviias uzn'emeyiem? I. Shteinbuka (Zin. red.). Produktivitates celshana: tendences un nakotnes izaicinaiumi. Riga: LU Akademiskais apgads, 159.-172. lpp. (In Latvian)

48. Susskind, D. (2020). A world without work: Technology, automation and how we should respond. Metropolitan Books.

49. Tikhonova, N. (2006). Resursnii podkhod kak novaia teoreticheskaia paradigma v stratifikatsionnykh issledovaniiakh. Sotsiologicheskie issledovaniia, № 9, s. 28-41. (In Russian)

50. University of Latvia. (2020). Profesionala magistra studiuu programma "Rakstiska tulkoshana". Retrieved from: https://www.rakstiskatulkosana.lu.lv/merki-uzdevumi/. (In Latvian) 
51. Ventspils University of Applied Sciences. (2020). Magistra studiiu programma "Lietishkio tekstu tulkoshana". Retrieved from: https://venta.lv/program/lietisko-tekstu-tulkosana/. (In Latvian)

52. Villani, V., Pini, F., Leali, F., \& Secchi, C. (2018) Survey on humanrobot collaboration in industrial settings: Safety, intuitive interfaces and applications. Mechatronics, Vol. 55, pp. 248-266.

53. Vinge, V. (2001) True names: And the opening of the cyberspace frontier. J. Frenkel (Ed.). New York, NY: Tom Doherty Associates, LLC.

54. Wilson, H. J., \& Daugherty, P. R. (2018). Collaborative intelligence: Humans and AI are joining forces. Harvard Business Review, Vol. 96, pp. 108-116.

55. World Economic Forum. (2017). The Global Competitiveness Report 2017-2018. K. Schwab (Ed.). Geneva: World Economic Forum.

56. World Economic Forum. (2018). The Global Competitiveness Report 2018. K. Schwab (Ed.). Geneva: World Economic Forum. 